\title{
DEBT IN RELATION TO THE STANDARD OF LIVING ENJOYED BY THE POPULATION OF DEVELOPED COUNTRIES
}

\author{
Luboš Smrčka, Markéta Arltová*
}

\begin{abstract}
The paper attempts to analyse the effects of the cumulated public sector debt (in this relation essentially government debt and family debt), primarily on the development of the population's standard of living. In this regard, the paper quantifies the impact of debt on the real standard of living - whether we define it merely as the ability to consume, or broadly as the sum of multiple criteria including, for instance, the quality of the environment. This quantification uses data from the economy of the Czech Republic; however, this method can be in principle used for other national economies, but must be adjusted to reflect the specific features of their development. Using the analysis of time series, the paper investigates some other aspects of the debt situation of families in the Czech Republic, especially the development of the relationship between families' savings and debt, and finds that debt prevails over savings in the long run. Several conclusions for the future can be derived from these results. These conclusions can be summarized in a statement that future political representations will have to continuously bridge the gap between the need to reduce the standard of living of large groups of the population on the one hand, and the need to make sure that the necessary reforms are politically viable on the other hand.
\end{abstract}

Keywords: debt crisis, Eurozone crisis, gross domestic product, mortgage crisis, public budgets, standard of living.

JEL Classifications: D1, C5

\section{Introduction}

In economic terms, we have witnessed two financial crises in the past years, each with its own distinct character. Another cataclysm will inevitably follow.

The first of the two events was the deep and destructive financial crisis of 2007 and 2008, marked with events such as the fall of Lehman Brothers.

The second event is the government debt crisis which is sometimes referred to, albeit somewhat erroneously, as the Eurozone crisis. The fact is, however, that it has affected public finance in basically all developed countries of the world. Formally speaking, while the downturn began in 2009 , its origins may be traced to decades in the past. And it is

* University of Economics, Prague, nám. W. Churchilla 4, CZ - 13067 Prague 3 (smrckal@vse.cz, arltova@vse.cz), The article is one of the outputs of a Research Project carried out by the Faculty of Business Administration, University of Economics, Prague, Czech Republic, New Theory of Business Economics and Management of Organizations and Their Adaptation Processes, File No. MSM 6138439905, and with the support of the Grant Agency of the Czech Republic No. P402/12/ G097 DYME Dynamic Models in Economics. 
only difficult to predict how much longer it is here to stay although the most visible signs of the crisis are likely to persist at least throughout the period of 2010 to 2015. Whether we are to see a resolution of the issues at its end remains uncertain and, actually, highly doubtful. This particular crisis may be referred to as the "public debt crisis".

What comes next? We are likely to experience a third wave of deep and global financial turmoil, marked by the liquidity crisis of households in developed countries, their incapacity to honour their commitments and widespread insolvency. These three events mark the end of a certain idea of how the global financial markets work and how debtors and creditors act.

Unfortunately, this does not mean that there will thereafter be a period of low debts, budget discipline, careful family planning and rational treatment of finance in general.

Quite the contrary: Let us express a hypothesis that developed countries will for various economic and political reasons be unable to consolidate public budgets, and their societies will be unable to control their family budgets to a large degree that can be deemed as having destructive societal effects. We can express a crucial and undoubtedly almost heretical idea: these states and their citizens are for various reasons unable to reduce their standard of living by gradual steps so as to gain the ability to repay their public and family debts. However, this would imply that if no rational outlook for an evolutionary resolution of the situation exists, a revolutionary resolution, i.e. a solution in the form of "a giant leap" must inevitably follow. For our purposes, we can call it a process of "financial cataclysm".

\section{Beginnings of Crises in the Developed Countries}

If we examine the nature of the individual components of the financial crises that have been shaking the world economy since 2007 with at least some care, we can get a glimpse of their causes.

Let us take first the US mortgage market crisis, which was indisputably caused by an entirely ineffective regulation of the whole system, combined with the governmental agencies' drastic (albeit sometimes indirect) subsidies to the mechanism.

In addition to tax reliefs, semi-governmental organisations provided guarantees for the loans granted. The federal government thus pumped at least USD 3.5 billion into the system from 2000 to 2007 (Smrčka, 2009). And while this is a mere estimate of only the demonstrated costs or the guarantees really made, the question remains what money was injected into real estate thanks to the cheap money policy promoted by the Federal Reserve system.

In any case, it was precisely this money that helped to trigger two parallel phenomena: first, the creation of the real estate bubble that entailed a substantial overvaluation of real estate; and second, the fact that hundreds of thousands of households incurred debts, including households that in view of their economic performance would not have had 
any chance of obtaining a loan under standard conditions. An entirely perverse system of subsidies to real estate ownership created absurd situations in which families took on mortgage loans designed, by a political decision, to ensure home ownership "for everyone", although they had been the owners of the mortgaged property long before. Therefore, "home ownership" remained the same but the family obtained a loan for its own consumption, i.e. to improve its real standard of living beyond the standard of living given by the economic performance of the family through debt, albeit debt that was formally guaranteed and in reality made cheaper by governmental policy.

The developed countries' debt crisis and the real estate crises in the USA and in dozens of other countries share many common features. Let us observe debt per capita figures in the individual OEDC member states, for instance.

Table 1

Gross Public Debt per Person (USD PPP)

\begin{tabular}{|l|r|r|}
\hline & $\mathbf{2 0 0 7}$ & $\mathbf{2 0 1 0}$ \\
\hline Estonia & 1545 & 2549 \\
\hline Korea & 7310 & 9924 \\
\hline Australia & 5351 & 10089 \\
\hline Slovak Republic & 6861 & 10738 \\
\hline New Zealand & 7200 & 11377 \\
\hline Czech Republic & 8285 & 12149 \\
\hline Poland & 8674 & 12305 \\
\hline Slovenia & 8166 & 13388 \\
\hline Hungary & 13909 & 18047 \\
\hline Luxembourg & 9864 & 18218 \\
\hline Switzerland & 20028 & 18530 \\
\hline Sweden & 18987 & 19480 \\
\hline Finland & 14968 & 21123 \\
\hline Denmark & 12958 & 21636 \\
\hline Spain & 13585 & 21648 \\
\hline Israel & 20660 & 22326 \\
\hline
\end{tabular}

\begin{tabular}{|l|l|l|}
\hline & $\mathbf{2 0 0 7}$ & $\mathbf{2 0 1 0}$ \\
\hline OECD31 & $\mathbf{1 8 7 0 2}$ & $\mathbf{2 5 9 4 7}$ \\
\hline Portugal & 18255 & 26425 \\
\hline Norway & 31569 & 28134 \\
\hline United Kingdom & 16861 & 29507 \\
\hline Netherlands & 20992 & 29972 \\
\hline Austria & 23823 & 31428 \\
\hline France & 24074 & 32606 \\
\hline Germany & 23301 & 32961 \\
\hline Canada & 25512 & 33208 \\
\hline Belgium & 31367 & 37850 \\
\hline Ireland & 13043 & 40141 \\
\hline Greece & 31884 & 41353 \\
\hline Italy & 35971 & 41986 \\
\hline Iceland & 19804 & 43232 \\
\hline United States & 28856 & 44616 \\
\hline Japan & 56090 & 67423 \\
\hline
\end{tabular}

Source: OECD (2011)

In 2010, the OECD countries' purchasing power parity averaged at USD 25,947. Please note that the countries hit by the crisis worst are at the very bottom of the table, i.e. their 2010 debt per capita ranked among the highest ones.

Of course, the dramatic growth of debt between 2007 and 2010 is a fact of similar importance - only two OECD states managed to reduce their debt between those years 
- Norway and Switzerland. All other countries chose not to combat the effects of the crisis by balanced budgets and discipline, but by a dynamic growth of debt. This is well illustrated by the following table:

Table 2

General Government Gross Debt as a Percentage of Nominal GDP

\begin{tabular}{|l|r|r|r|}
\hline & $\mathbf{2 0 0 0}$ & $\mathbf{2 0 0 7}$ & $\mathbf{2 0 1 0}$ \\
\hline Estonia & 9.4 & 7.3 & 12.1 \\
\hline Luxembourg & 9.2 & 11.7 & 19.7 \\
\hline Australia & 24.6 & 14.2 & 25.3 \\
\hline Switzerland & 52.4 & 46.8 & 40.2 \\
\hline Korea & 19.0 & 27.9 & 33.9 \\
\hline New Zealand & 36.9 & 25.7 & 38.7 \\
\hline Slovak Republic & 57.6 & 32.8 & 44.5 \\
\hline Sweden & 64.3 & 49.3 & 49.1 \\
\hline Slovenia & 33.7 & 30.0 & 47.5 \\
\hline Czech Republic & 30.5 & 33.7 & 46.6 \\
\hline Norway & 32.7 & 57.4 & 49.5 \\
\hline Denmark & 60.4 & 34.3 & 55.5 \\
\hline Finland & 52.5 & 41.4 & 57.4 \\
\hline Poland & 45.4 & 51.7 & 62.4 \\
\hline Spain & 66.5 & 42.1 & 66.1 \\
\hline Netherlands & 63.9 & 51.5 & 71.4 \\
\hline OECD31 & 59.4 & 55.6 & 74.2 \\
\hline Israel & 84.5 & 77.7 & 76.1 \\
\hline Austria & 71.1 & 63.1 & 78.6 \\
\hline Canada & 82.1 & 66.5 & 84.2 \\
\hline UK & 45.1 & 47.2 & 82.4 \\
\hline Germany & 60.4 & 65.3 & 87.0 \\
\hline Hungary & 60.8 & 72.5 & 85.6 \\
\hline France & 65.6 & 72.3 & 94.1 \\
\hline USA & 54.5 & 62.0 & 93.6 \\
\hline Portugal & 60.2 & 75.4 & 103.1 \\
\hline Ireland & 39.4 & 28.8 & 102.4 \\
\hline Belgium & 113.7 & 88.1 & 100.7 \\
\hline Iceland & 53.3 & 120.2 \\
\hline Italy & 112.8 & 126.8 \\
\hline Greece & 112.9 & 147.3 \\
\hline Japan & 167.0 & 199.7 \\
\hline
\end{tabular}

Source: OECD (2011) 


\section{Debt and Standard of Living}

By the end of 2011 (the dating of the text) Iceland, Ireland, Greece, and Portugal had undergone a de facto state bankruptcy, with Italy, potentially Spain and very probably Belgium next in line. France and other countries are in serious danger. Cypruss is in a critical state, the situation in Slovenia and Hungary is very serious. Two developed countries have not become insolvent by a mere coincidence: the United States because they can print a virtually unlimited quantity of new dollars, and as long as the dollar remains the reserve currency, they can export their problem overseas. In addition, the USA can rest assured that although the dollar is retained as the reserve, the influx of dollars from overseas in the US economy will not dry out because the dollar cannot be ultimately realised anywhere else. The second country that enjoys a rare and extraordinary advantage is Japan. Its astronomical debt is owned primarily by the citizens; the government keeps drawing from household savings that are extremely high due to a combination of various factors. The Japanese public debt is not exposed to the turbulent markets, with only six percent of the debt denominated in foreign currencies. Therefore, with the low yen rates, the debt service is very cheap. According to OECD data, the Japanese government spent only 2.5 percent of the country's GDP on debt service both in 2007 and in 2009 (newer data is unavailable). Just to compare, Iceland spent $6.6 \%$, Greece $5.3 \%$, Italy $4.6 \%$, Hungary $4.5 \%$ of its GDP on debt service in 2009, and the list goes on.

\section{a. Principle of the public budget crisis}

Whatever the specific reasons of the individual components of the cascading financial crisis, their essence always remains the same - the really achieved standard of living clashes with the living standard that would match the true economic performance of the given country. The Czech Republic can serve as the perfect illustration.

We rely on the hypothesis that any government debt, or public debt in general, will sooner or later lead to a growth of the households' disposable income. This is given by the principle of debt consumption - if the debt is drawn to retain the state's ability to make, for instance, pension or social benefit payments, or to fulfil its duty to pay wages to civil servants or employees of governmental organisations or institutions, the debt will always pass on to the available income directly. If the debt is drawn for building projects or for similar "development" projects, it is used to implement projects or purchase goods that would not have been implemented or purchased otherwise. Nevertheless, domestic product that would not have otherwise come into existence is created, and similarly, wages that would otherwise not have been paid are paid, or profit that would have been lower or non-existent without the public sector debt is generated. Therefore, public sector debt will always be transformed into available income.

The scope of this transfer is open to discussion. However, this discussion lacks corresponding content - we do not know what payments would have been sacrificed 
if the government (or municipality) had been unable to borrow the money; therefore, we can easily say that the debt is used to pay pension or social benefit payments or to make transfers to households in general, or to pay wages, i.e. that it is transformed into disposable income for households in direct and in absolute terms.

If debt is not incurred as a result of rising expense but of dropping income, e.g. by reduced tax burden, the effect remains the same. If taxes fall without the state adequately curtailing outgoing payments, the public sector pays more money to individuals and corporations alike without reducing the comfort created by the state (or course, we can debate indefinitely as to whether this comfort is beneficial or ineffective - but this question is irrelevant in this case). This comfort supplied by the state is also an expression of the standard of living - be it in the form of unemployment benefits or a specific number of students in a standardised elementary school class, i.e. in the number of teachers available to the education system. Reduced tax increases net income, i.e. it is directly reflected in the standard of living by means of higher available income.

It is thus irrelevant whether public budgets incur debt through rising expense or reduced income - debt is in all standard situations a direct subsidy to the standard of the citizens' living. (Of course, there are rare exceptions, e.g. foreign military ventures by states purchasing weapon systems and other equipment from foreign suppliers; nevertheless, this surely is not the case of any of the countries facing a debt crisis at the moment.)

Debt is sometimes spun as "investment" aimed to increase the economy's future resistance and to kick-start economic development in general. However, as has been proved beyond any doubt, extremely indebted countries do not boast any substantially higher proportion of hi-tech economy than countries with significantly lower debt indicators (Tučková, Strouhal, 2010).

\section{b. Inflation is not a solution}

We have thus come to the conclusion that the accumulated public debts have spurred a growth in their citizens' standard of living, and that their "true" standard of living, i.e. the standard truly experienced by the citizens, exceeds the standard that would have been experienced by the same citizens were it not for the public budget deficits. Of course, this conclusion hardly comes as a surprise.

For instance, Michael Pento, senior economist at Euro Pacific Capital, Inc., wrote the following in his article, emotively entitled Say Goodbye to Your Standard of Living, Inflating Away America's Future: "The consequences for the future economy are clear: Living standards are set to decline dramatically, especially for those who have the least time to prepare. We must balance our budget, boost the value of the dollar, lower inflation, cut taxes, reduce regulations and introduce competition back into our educational system. That is the best hope for America's future. Since the bond vigilantes are currently busy 
over in Europe, the U.S. may have a little bit of time remaining" (Market Oracle, 2012). We can find many similar warnings in what is essentially journalistic writing. Nevertheless, this issue has been neglected by scientific research in economics.

However, another, often forgotten fact must be pointed out in this context: all debt repayment methods are detrimental to living standards, although some methods may defer this detrimental effect to some extent or partially mask it as the result of other factors. Be it debt monetisation or repayment through inflation, or even if we forced the investors to write off a part of the debt, the problem will still be reduced to the key point of all our considerations one way or another. If the investors write off a part of the debt, it will primarily mean that the assets will be written off by the banks with the full impact of this step - the need to strengthen capital, to suffer substantial loss that will be ultimately transferred to the states and the bank's shareholders and, in the form of rising fees or interest differential, to all banking sector clients who will have to pay the increased cost. Even inflation triggered to reduce the actual debt by depreciating currency will in reality always reduce the standard of living, to say nothing of the fact that the banks will suffer again, which will again put public budgets under increased pressure as the banks' capital will again have to be strengthened. And so on.

However, the time has come to ask whether we can somehow foresee the extent to which the living standard in developed countries will have to be reduced so that these countries' sovereign debt, or a part thereof, could be repaid?

\section{c. To what extent is the standard of living artificial?}

Therefore, we must identify the extent to which the current standard of living in the developed countries exceeds the standard that would match their economic performance.

In doing so, we will have to tackle the first problem - lack of consensus as to the indicators by which a term of such vagueness as the "standard of living" can be measured.

The fundamental dispute is whether the standard of living can be in principle measured separately by real purchasing power, or whether a more complex system of values and parameters must be defined (e.g. safety and crime level, quality of the environment, enforceability of law etc.). Without engaging in this debate, it will suffice for our purposes to perform a basic comparison through the quantity of money available to an average household, i.e. using the available income.

This indicator is expressed in national units, just like debt, which allows us to compare government budget deficits to household disposable income.

So far, we have not mentioned another type of debt, which has already grown to enormous proportions and which will only grow in the future - household debt. One cannot ignore the fact that household debt in the developed countries has witnessed a dramatic growth in the past two decades or so. If we look at the impact of household debt on the standard of living, this correlation is purely direct and even less prone to 
argument than the relation between public budget deficits and the citizens' standard of living. Household debt clearly constitutes direct purchase of a standard of living in excess of present income. Families mostly assume that their income will grow in the future, i.e. that the repayment will not be as painful and will not entail drastic savings; nevertheless, this model is fragile, and depends on the development of the household's economic situation. In today's cascading, systemic financial crisis, one cannot assume the household income in the developed countries to witness a dramatic growth in a few, let us say, five years ahead. Therefore, a model based on debt repayment through growth, which formed the basis of the strategy adopted by millions of families in the developed countries, now seems very unlikely.

In an attempt to express the "artificial" portion of the standard of living, we will analyse the situation in the Czech Republic.

\section{d. Impact of sovereign debt on the standard of living in the Czech Republic}

To identify the extent to which assumption of debt by the public budgets and by households affects the standard of living, we must primarily compare the debt development with the development in the disposable income of households. We have concluded that the volume of household debt constitutes the direct price paid to "purchase a standard of living", i.e. that the debt becomes a direct accelerator of the living standard. In this respect, the situation is perfectly clear.

We have already mentioned the question as to what extent can we deem public debt to form a part of family income. We have also concluded that the assumed government debt will sooner or later become a part of the income available to families - the question is not if, but when. Nevertheless, to reflect this impact and bearing in mind that some public budget deficits will not inevitably end up in household economy, but may serve to pay for imported goods and services, we will reduce public budget debt to 0.75 of its real figure.

Table 3

Budget Deficit (75 percent) and Household Debt pro rata disposable Income of Households

\begin{tabular}{|l|r|r|r|r|r|r|r|r|r|r|}
\hline Year & $\mathbf{2 0 0 1}$ & $\mathbf{2 0 0 2}$ & $\mathbf{2 0 0 3}$ & $\mathbf{2 0 0 4}$ & $\mathbf{2 0 0 5}$ & $\mathbf{2 0 0 6}$ & $\mathbf{2 0 0 7}$ & $\mathbf{2 0 0 8}$ & $\mathbf{2 0 0 9}$ & $\mathbf{2 0 1 0}$ \\
\hline Disposable income & 1,293 & 1,348 & 1,409 & 1,474 & 1,551 & 1,675 & 1,833 & 1,987 & 1,976 & 2,000 \\
\hline $\begin{array}{l}\text { State budget } \\
\text { deficit (0.75) }\end{array}$ & 51 & 34 & 82 & 71 & 42 & 74 & 50 & 14 & 144 & 117 \\
\hline $\begin{array}{l}\text { Family debt } \\
\text { balance }\end{array}$ & 17 & 41 & 57 & 76 & 101 & 133 & 222 & 157 & 74 & 28 \\
\hline $\begin{array}{l}\text { Deficit + debt } \\
\text { balance }\end{array}$ & 68 & 75 & 139 & 147 & 143 & 207 & 272 & 171 & 218 & 145 \\
\hline $\begin{array}{l}\text { Share in available } \\
\text { income }\end{array}$ & $\mathbf{5 . 3}$ & $\mathbf{5 . 6}$ & $\mathbf{9 . 9}$ & $\mathbf{1 0 . 0}$ & $\mathbf{9 . 2}$ & $\mathbf{1 2 . 4}$ & $\mathbf{1 4 . 8}$ & $\mathbf{8 . 6}$ & $\mathbf{1 1 . 0}$ & $\mathbf{7 . 3}$ \\
\hline
\end{tabular}

Note: all data in CZK bn., share in available income in percentages.

Source: Czech Statistical Office (2009), Dubská (2010). 
Most importantly, this table requires a certain interpretation and explanation of some data. Disposable income (which should be the equivalent of Czech disposable household pension) expresses the volume of financial resources gained by Czech families in a given year after taxing their incomes and after deductions by law. This datum, however, has not been adjusted by such payments as those which stem from contractual obligations of families - e.g. from down payments, insurance payments and so forth. The deficit of the state budget is new government debt accepted in a given year; it is only generally connected with the entire government debt as a quantity accumulated in years. Family debt balance, (which should be the equivalent of the Czech balance of household debt) shows increased household indebtedness in a given year. This indicator has not been adjusted by the growth of deposits or financial assets or assets in general, which seems methodically dubious at first glance, although we are proceeding from the hypothesis that household debt is a structured datum. In the Czech environment, it applies that the greatest growth of debt can be observed in households with the lowest incomes and then, on the other hand, households with the highest incomes. Savings among households with the lowest incomes do not grow, nor have they grown during the stated period, whereas its financial savings actually dropped at its end (2008 to 2010); therefore, in their case, the increase of debt cannot be considered a minimally "adjusted" figure. Furthermore, after including the drop in financial savings (equivalently deposits, given the fact that this is a truly dominant form of financial savings in the Czech environment), the group of households with the lowest incomes would show still much worse data. Among households with the highest incomes, financial savings did increase slightly or at least stagnated also during the period of their coming strongly into debt, but even here we have refrained from attempts to adjust this datum. In any event, it applies that debt grew more rapidly than did deposits, especially in the second part of the observed period; moreover, the date on new household debt does not include the debt service accepted with this debt and in the end, the debt in these households served primarily towards the transformation of financial resources into immovable assets, the liquidity of which dropped significantly following the bursting of the real estate bubble, even by tens of percent. Real estate prices reached their peak in 2007 and 2008; in 2009 and 2010, real estates were considerably liquid, and on the basis of knowledge from the beginning of 2012, we can assume the prices of real estate will, at least in the period until 2015 (but more likely considerably longer), be thirty and more percent lower than the level during 2007 and 2008. From this perspective, therefore, the possible growth of financial savings of households with the highest incomes is problematic.

As indicated by Table 3, the share of government budget deficit (reduced to $75 \%$ of its original amount) and the positive balance of debt assumed by Czech households have reached substantial amounts throughout the years. Please note that this share climaxed during the biggest economic growth mainly due to the high household debt numbers. By contrast, the crisis years of 2009 and 2010 saw a dramatic increase in the effect of social benefits and redistribution of funds, i.e. the rising importance of budget deficit. 
Let us briefly return to the chosen coefficient of 0.75 - this way, we will reduce the effect of government debt on the rise of the standard of living based on the assumption that not all the money spent by the government from its budget deficit will translate directly into artificial growth of the standard of living. This three-quarters effect is a purely theoretical index, and the real proportion is probably higher; however, as a general precaution, it is better to use a figure that may be less likely but that does not entail the risk of artificially increasing the effect and the need to index the original figure in any way.

The $75 \%$ proportion is based on the proportion of the imports to the gross domestic product created by the Czech economy in 2010: total imports of goods reached CZK 2.4 billion, while the gross domestic product totalled CZK 3.7 billion. However, the fact that the state is not primarily a major importer had to be taken into account, too.

\section{e. Some comments on other aspects of debt}

We have shown that the debt of families and government, which went on to witness substantial growth in the Czech economy especially in the new Millennium, was, and still is, likely to have a very decisive effect on the overall standard of living enjoyed by the population. Of course, this leads to many other questions.

For instance, we could argue that this impact on the living standard is visible only if we understood this indicator in terms of pure consumption, i.e. as the ability to consume. In other words, if we understood "standard of living" as a phenomenon mechanically connected to the sums that the population is able to pay for its consumption in the broad sense of the word, i.e. that this "argument by debt" does not entail questions such as the quality of the environment, safety etc.

This objection is meritless. If we used a very naïve but practical analogy in this case that all the debt was consumed to improve the environment and to increase safety, we would achieve a certain standard of living in these areas. If the funds were used correctly, we could probably say that the air is cleaner, the water is healthier, smaller quantities of heavy metals pollute nature, and some species have been saved from extinction. Similarly, we could argue that murders, thefts and other crimes were on the decline. Nevertheless, environmental preservation and protection of safety have their own expenses to be spent in the future. These expenses are clearly derived from the level currently achieved and are related to the current funding of environmental protection mechanisms (e.g. wages paid to competent officers) or to the funding of security corps and their equipment, the technologies used and their usable life. High past expenses inevitably lead to high future expenses depending on the achieved quality of the public estate.

The proportion between past and future expenses will understandably vary widely depending on the characteristic features of the cases at hand. For instance, future costs of funding security corps can be a priori labelled as constantly growing costs, if only because inflation must be eliminated and demands for the growth of real wages can be expected. Similarly, the price of equipment used by the security corps will inevitably 
witness a constant growth. The same will apply to wages and common equipment of the environmental officers; however, the situation will differ for necessary investments, which usually enjoy a relatively long usable life. However, when observing a relatively long timeframe, we can see the costs of preserving the status quo grow in the future, too.

In other words - if we want to reduce the accumulated debt that would be incurred (in our theoretical world) by funding the quality of environmental protection and safety, we will have to stop providing sufficient funding to these areas in the future, which, however, will reduce both parameters. And given that we included these parameters in the evaluation of the overall standard of living, the end of sufficient funding will translate into a corresponding drop in the standard of living measured in this holistic manner.

Therefore, we can see it is irrelevant whether we define "standard of living" to include only the ability to consume or add other aspects of life - the need to repay debt will always be reflected in any definition we may choose.

\section{Analysis of Some Aspects of Debt}

One of the extremely interesting circumstances of the growth of government and family debts is its relationship to the development in the primary deposits of families, i.e. to the development of the families' financial assets.

At first sight, the relationship to government debt escapes us, of course. Nevertheless, quite an interesting thought offers itself: can government debt and family debt share any features in terms of their development in time? Certain relations shown in Table 3 are already interesting and raise many questions. For instance, we can see that household debt and government debt are mutually "complementary". Periods of high growth in family debt witness slower growth of government debt. It works the other way around, too - if government debt shows a really dynamic growth, we can see the family debt growth decelerates. This phenomenon is probably related to the economic cycle: we see faster growth of debt of the Czech Republic primarily in periods when the economy slows, and later stops or even enters recession.

However, matters are not so simple. If we were to carefully analyse the family debt development, we would see a dynamic growth that continued to gather speed until 2007; new debt was still enormous in 2008 and while it decelerated in 2009, it was still high.

In this context, we have to realise that Czech budget deficits were marginal and government debt was not worth mentioning throughout the nineties. It was the crisis of the Czech koruna in 1997 and the subsequent recession of 1998 through 2000 that motivated Miloš Zeman's cabinet in power at that time to support the economy with a budget deficit; however, this deficit was still hardly significant and in looking back, the volumes of debt were essentially marginal. However, the later governments failed to control this development, which can be seen as a trend that mirrored the development 
of family debt - Czech households in 2000 had no debt to speak of, and the dynamic assumption of debt seemed to follow the "example" set by the government.

We can speculate whether the beginning of the era of deficit-based government funding helped Czech families to break the psychological barriers by "legitimising" debt. This is an interesting possibility that should not remain unnoticed - although the main role will rather be played by the general development of the economic environment and the evolution of the mortgage market. Although this is a reflection that digresses slightly from the main direction of the text, it is fitting to pause briefly in this area.

The mortgage market in the Czech Republic opened substantially earlier than the period when families started to become massively indebted - as early as in the second half of the 1990s. It is, however, true that the price level of mortgages was quite high at that time and did not allow the majority of families to consider such a means of financing real estates - interest bearing for mortgages was in the vicinity markedly above ten percent; and although this price was alleviated by state subsidies (paid interests were tax deductible, a part of the interests were directly subsidised), mortgages were very expensive in view of the income situation of families. This also affected the economic crisis in the Czech Republic, which followed after the currency tremors of 1997 and transformed into the recession of 1998. The entire banking sector was then in a thorough depression until the comprehensive privatisation at the turn of the century.

Price regulation in the area of rented housing, which kept expenses in the decisive part of the market (which was subject to regulation) very low, also had a significant influence. Regulation thus preserved the housing market and, on the contrary, increased prices in the area of housing that was not subject to regulation. The result was a state in which there was an evident lack of flats - which led immediately to their sharp increase as soon as mortgage prices dropped.

Even so, the state's approach to indebtedness had to have an effect on the attitudes of families. The opinion towards debt was quite conservative in Czech tradition, which arose from the heritage of the Czechoslovak Republic (1918-1938), the economic management of which was exemplary in this area. Even during the period of communist dictatorship and planned economy (1948-1989), what was then the Czechoslovak Socialist Republic was, during the greater part of this era, a state whose debt was marginal. A marked change in the state's approach to debt, which was conditioned by the need to get the economy moving after serious problems in 1997 to 1998 , most certainly helped to pave the way also to a change of approach among Czech families.

\section{a. Analysis of families' financial savings and debt}

Speaking of family debt, it is undoubtedly interesting to look at its relationship to savings. This comparison offers an interesting array of conclusions.

Figure 1 shows the volume of credit and deposits of Czech households in 1990-2011 (in millions of Czech korunas). 
Figure 1

1990-2011 Household Credit and Deposits in the Czech Republic (in CZK mil.)

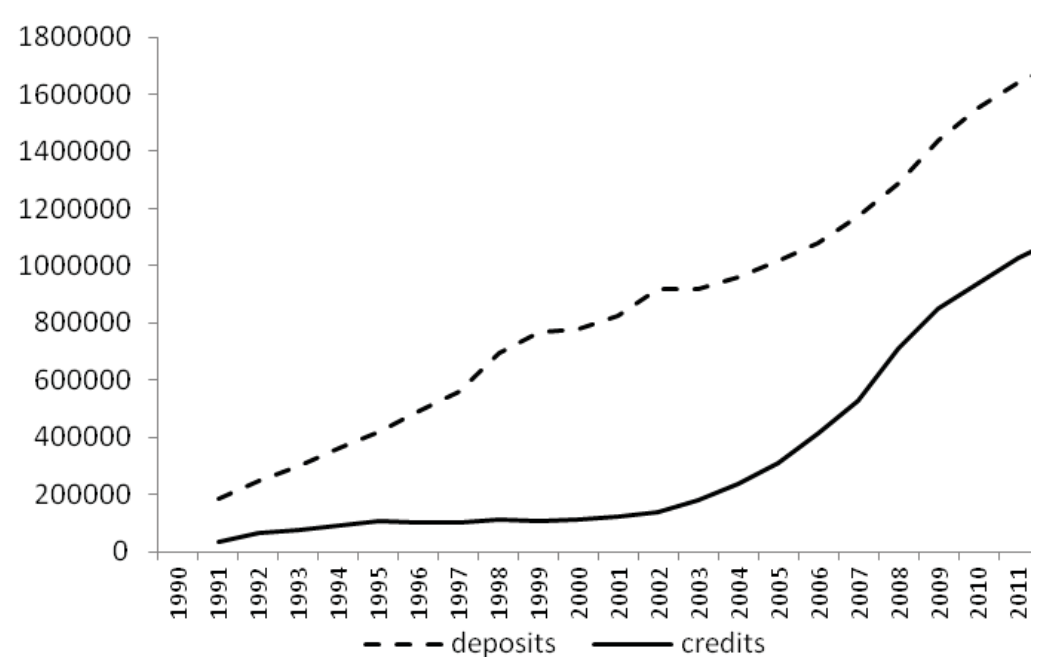

Source: Czech Statistical Office (2012)

Both time series are characterised by pronounced, almost exponential, growth. Comparing the dynamics of the two indicators, the average rate of growth clearly shows that the average growth of household credit (18.9\%) exceeds that of deposits (11.6\%). While household deposits have been growing continuously throughout the observed period, household credit, overcoming the initial stagnation, did not witness rapid growth until 2000 , when it grew by $23.7 \%$ per year on average.

Of course, inflation must be added to this picture: inflation had a substantial impact on all monetary and financial indicators of the Czech economy primarily in the first half of the nineties. Therefore, it is important to realise that although deposits nominally doubled in size between 1990 and 1994, real deposits remained the same or may have even witnessed a drop, as 1990 and 1991 in particular saw substantial currency depreciation due to the process of price liberalisation. Even the data for the subsequent five years is affected by the high rate of growth in consumer prices. By contrast, after 2001 inflation can be no longer deemed a serious enemy of the Czech economy, which actually had to face deflation tendencies at times.

A look at the proportion of household credit to deposits is also interesting (Figure 2). 


\section{Figure 2}

Proportion of Household Credit to Deposits in the Czech Republic from 1990 to 2011 (in \%)

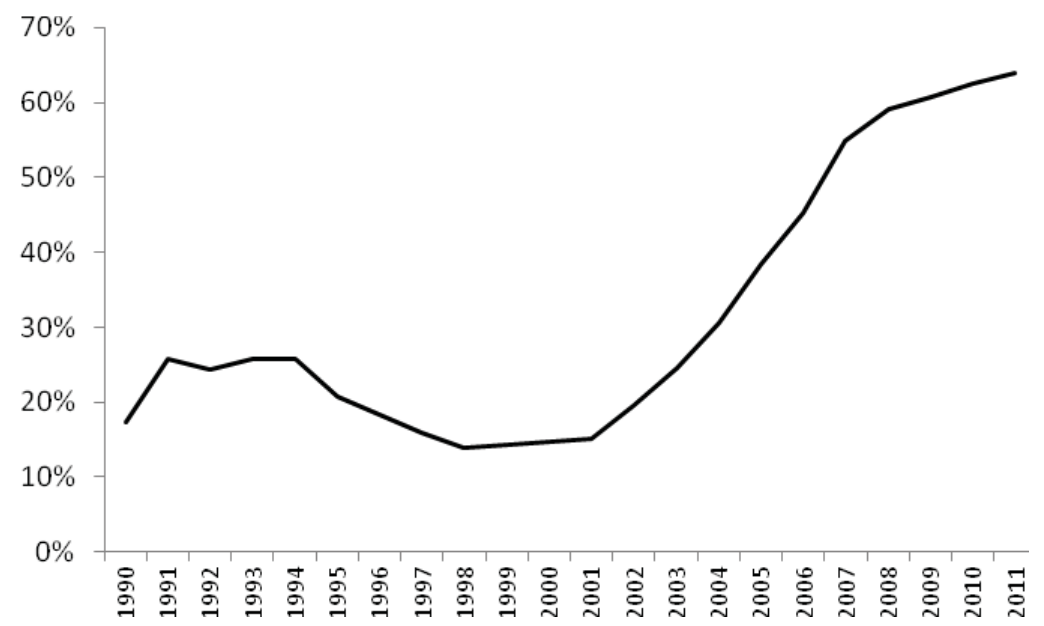

Source: author's calculation

The development of this proportion can be divided into three stages: from 1990 to 1994 , the proportion grows from 17 to $25.8 \%$, then drops from 18 to $14 \%$ between 1995 and 2001, and witnesses a sharp rise up to $63 \%$ from 2002 on.

We can define the first stage as the first period of reforms, a radical transformation of the Czech economy from a centrally planned system to a market economy. Banking services were dramatically underdeveloped, and the governments of that time followed the official policy of an essentially balanced budget. The citizens had no opportunity or desire to take on debt; in addition, high inflation meant that money was relatively expensive in real terms, too. On the other hand, the "small privatisation" and other privatisation efforts were under way in that period, which increased the demand for credit aimed in that direction. Significant portions of these credits were assumed by private individuals and thus acted as family debt. That was the main reason why the volume of money deposited by the citizens in banks, which were in turn loaned by the banks back to citizens, witnessed a growth in that period.

The years 1995 through 2001 saw a stagnation of credits, and the proportion of deposited funds used to provide credit to households dropped as a result. Again, this follows perfect logic. The wave of privatisation was over, and families still had no motivation to take on debt. Money was still expensive and, in addition, the Czech koruna went through a small, local monetary crisis in 1997. The koruna's exchange rate faced immense pressure from speculators, and one of the results of the crisis, aggravated by a slowdown and later even recession of the economy, was the temporary sharp increase of the key rates of the Czech National Bank and a stricter set-up of the general conditions on the banking market. The 
Czech banking sector went through a tough healing process, with more than ten banks disappearing from the market in the second half of the nineties.

The period after 2002 can be defined as the true boom of household debt - the truth remaining that most of these loans were drawn for housing purposes. Nevertheless, we can see that at the end of 2010, no less than 63 percent of total household deposits were used for credits.

If we were to analyse the relationship between credit and deposits of Czech households on the basis of quantitative analysis, we would conclude that although Figure 1 might indicate a relatively strong relationship between the two indicators, we would find that the relationship is only a spurious ("spurious regression" in the literature - e.g. Granger, Newbold, 1974, Arlt, 1997).

For this reason, we will try to add two further indicators in this relationship - the registered unemployment rate and household savings - which could help to capture the unexplained dynamics of the rest of the model.

We will therefore analyse the relationship between total household credit in millions of korunas, as well as between total household deposits in millions of korunas, the unemployment rate in percentages and the level of gross household savings during the period 1993-2011 (Figure 3).

Figure 3

1993-2011 Household Credit, Deposits, Unemployment Rate and Savings in the Czech Republic (in CZK mil.)

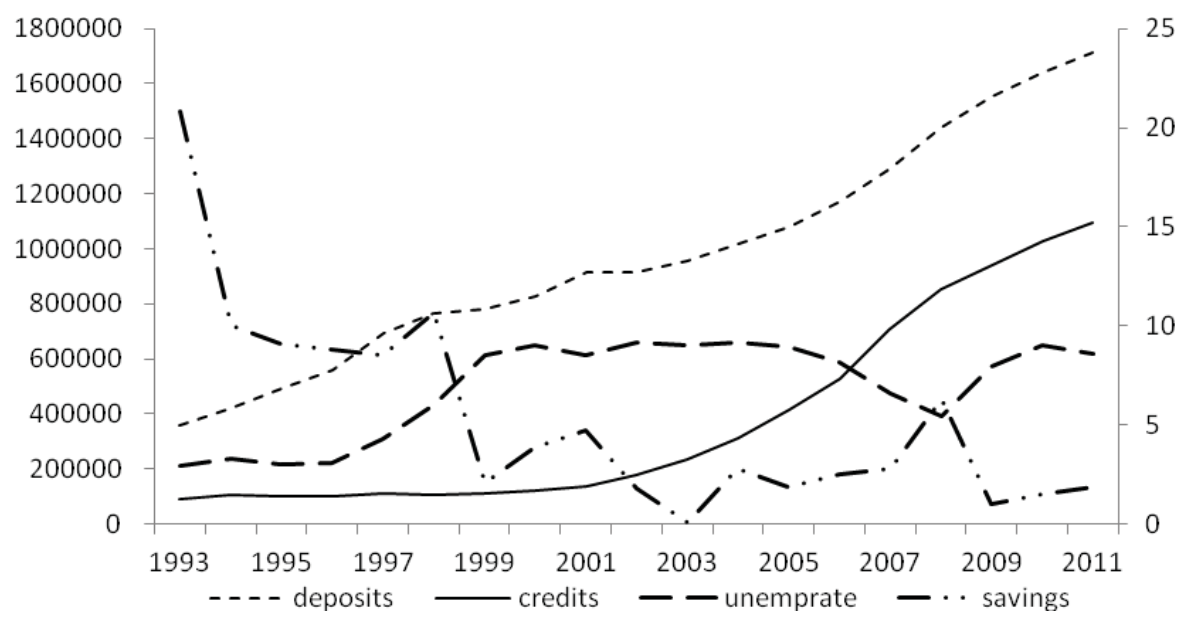

Source: Czech Statistical Office (2012)

In Figure 3, we see on the left vertical axis a scale in millions of korunas; percentages are given on the right axis. Deposits and credits are indicators that grow practically 
throughout the observed period, regardless of the economic cycle. This is understandably given by their volume character, which also contains in itself the aspect of inflation. As far as deposits are concerned, we see only two insignificant moments of deceleration in 1997 and in 2001. Otherwise, this parameter grew steadily and in a very similar way from as early as 1993 until the end of the observed period. Neither the crisis years 2007 to 2009 nor the subsequent stagnation of the economy manifested itself on this development in any significant way. A more interesting curve in terms of interpretation is offered by credits, where we can observe a very slow evolution in 1993 to the turn of the century. This is given by numerous influences, especially by the fact that Czech society had not been accustomed to the range of credits since the time of socialist planned economy and was also naturally conservative thanks to the tradition of the First Republic (1918-1938). Secondly, the range of bank products was not distinctly developed and loaning money to natural persons was in the nineties not among the priorities of banks operating on the Czech market. This changed markedly after the overcoming of the impacts of the crisis during 1997 to 1999, which begun by a currency exchange crisis elicited by pressure on the koruna exchange rate. These tremors led to serious problems in the Czech banking sector, which was until that time practically entirely in the hands of the state. A rapid privatisation of key banks ensued, and the range of products for households developed dynamically during the first years of the $21^{\text {st }}$ century. This is why we see such substantial changes in this parameter precisely after 2001. Deceleration after 2007 is, of course, a consequence of the financial crisis.

In modern Czech history, the unemployment rate has for the time being had a course that is only partially in harmony with the economic cycle. This is given by the development of privatisation and the long-lasting overemployment in the nineties that was kept alive thanks, among others, precisely to the above-mentioned state ownership of key banks. However, it seems that the Czech economy is currently set on an unemployment rate fluctuating in the vicinity of around eight to eight-and-a-half percent of able-bodied inhabitants. It seems that for further considerations we will be able to consider this level to be natural for the national economy of the Czech Republic.

Savings are indisputably the most interesting indicator in Figure 3. On the one hand, the sharp drop at the beginning of the nineties showed the increase in possibilities to satisfy needs, which was an area that was underestimated in the socialist economic system over a long time and its saturation was poor. The possibility to choose goods and services and, among others, also the possibility to travel abroad freely and without limitations led to dynamic changes in consumer possibilities for Czech households. Even despite growing incomes and a dynamic increase of the standard of living, society was unable to satisfy from new incomes the urge to increase consumption - this is why there is at the same time a drop in savings and we simultaneously observe a rise in credits.

But let us return from historical interpretation of data to their analysis.

In view of the character of the constructed model and the reduction of its variability, every time series was logarithmised; on the basis of Augmented Dickey-Fuller tests 
(ADF tests) (Dickey, Fuller, 1979), it was found that every time series is a non-stationary of I(1) type.

Table 4

Unit Root Test of the Log Time Series and of the First Differences

\begin{tabular}{|l|c|c|c|c|}
\hline \multirow{2}{*}{ 1993-2011 } & \multicolumn{2}{|c|}{ Time series } & \multicolumn{2}{c|}{ First differences } \\
\cline { 2 - 5 } & $\boldsymbol{t}_{\text {ADF }}$ & Prob. & $\boldsymbol{t}_{\text {ADF }}$ & Prob. \\
\hline CREDITS & -1.139328 & 0.6744 & -3.743356 & 0.0008 \\
\hline DEPOSITS & 1.702725 & 0.9740 & -2.471239 & 0.0164 \\
\hline SAVINGS & -0.831865 & 0.3398 & -3.660937 & 0.0014 \\
\hline UNEMPRATE & -1.907254 & 0.3213 & -2.577271 & 0.0134 \\
\hline
\end{tabular}

Source: own calculations

The analysis of relationships between integrated time series makes sense only when these time series are co-integrated, i.e. when they have a common stochastic trend. If the time series are not co-integrated, a state, the so-called spurious regression (Granger, Newbold, 1974) arises when analysing them with the aid of regression. We distinguish true regression from spurious regression by carrying out the Engle-Granger test of co-integration (Granger, Newbold, 1974), which is based on the analysis of residuals from the static regression model.

$$
Y_{t}=\boldsymbol{\beta}^{\prime} \boldsymbol{X}_{t}+a_{t} .
$$

If the residuals of this model are stationary $\mathrm{I}(0)$, then the time series are co-integrated, if they are non-stationary I(1), the regression is spurious.

Table 5

Unit Root Test of $a_{t}$

\begin{tabular}{|l|c|l|}
\hline \multirow{3}{*}{$a_{t}$} & $\boldsymbol{t}_{\text {ADF }}$ & Prob. \\
\cline { 2 - 3 } & -2.666889 & 0.0112 \\
\hline
\end{tabular}

Source: own calculations

From the Engle-Granger test of co-integration (Table 5), it follows that the residuals of the static model are stationary $\mathrm{I}(0)$, which rules out the possibility of spurious regression. But they are also auto-correlated, which is in the next step solved by a dynamisation of the model, i.e. by the construction of an ADL model.

The ADL model "Autoregressive Distributed Lag” (Hendry, Pagan, Sargan, 1984) with one lag, i.e. $\operatorname{ADL}(1,1)$ can be expressed as

$$
Y_{t}=c+\alpha_{1} Y_{t-1}+\beta_{1} X_{t}+\beta_{2} X_{t-1}+a_{t} .
$$


On the right side of the equation, there can be more explanatory variables and more lags. In a case of co-integration, an ECM (“Error Correction Model”) (Engle, Granger, 1987) can be derived from model (2).

$$
\Delta Y_{t}=c+\beta_{1} \Delta X_{t}+\gamma\left(Y_{t-1}-\beta X_{t-1}\right)+a_{t},
$$

where $\beta=\left(\beta_{1}+\beta_{2}\right) /\left(1-\alpha_{1}\right)$ and $\gamma=\alpha_{1}-1$. This model separately expresses short-term (between stationarised time series) and long-term (between untransformed non-stationary time series) relationships of time series.

The justification for using a single-equation model arises from various assumptions which, most importantly, contain the thesis that household credits are influenced by the evolution of the above-stated indicators; the opposite relationship, however, is not here. Household credits are thus in the model an endogenous variable, and the remaining time series have an exogenous character (Arlt, Arltová, 2009).

It is necessary to pause briefly at this assumption as it requires a certain argumentation. As we have stated several times, we will analyse the relationship between total household credits in millions of korunas, as well as between total household deposits in millions of korunas, the unemployment rate in percentages and the gross household savings rate during the period 1993-2011.

Formally, from the perspective of economic theory (e.g. Holman, 2005) there is an indisputable relationship between the unemployment rate and the volume of credits, as the rise in unemployment lowers the set of potential recipients of credits and uncertainty of income forms a significant group of consumers that is highly risky from the perspective of financial institutions. As we can see from the data, this relationship is marked in the timespan of approximately the last twenty years in the Czech Republic; in reality, however, other factors clearly affected the development. The opposite relationship, that is, influencing credits from the side of the unemployment rate, does not exist.

Household deposits are a reflection of the general retirement situation of households, whereas we must take into account that households are not a homogeneous group but, on the contrary, a system of highly varied smaller groups, inside of which the development is frequently markedly varied. Total family deposits in their absolute volume grow throughout the period covered by the researched data, which can be explained precisely by the fragmentation of sets of households into many smaller groups. We can deduce therefrom that the general retirement situation of families has improved and the consequences of the crisis have manifested themselves mainly on those groups that are socially the most sensitive. Nevertheless, relatively easy access to credits meant that the acceptance of new credits has positively affected household deposits. But it is possible to express the hypothesis that strong indebting of Czech households especially after 2001 (i.e. the development of credits) was strongly influenced by the fact that a significant part of households were unable to create further deposits as an expression of ability to saturate present and future consumption - this lack was then compensated by an 
increased demand for credits. This hypothesis cannot at the given time be verified by real data, as statistical data does not give us data on credits and deposits according to income types of families (for instance, according to deciles).

This aspect is reflected also in the last quantity, in savings, where it can with high probability be assumed that, since the end of the nineties, this rate was zero or even negative in a considerable number of families. The impossibility of reaching a positive or markedly positive value for savings led to further demand for credits. This led to a situation that fully manifested itself with the consequences of the crisis during 2007 to 2009 and with the stagnation of the economy and rise in the unemployment rate. The number of approved personal bankruptcies in the Czech Republic has already reached a level of more than thirty thousand cases and has been growing constantly, given that a further 24 thousand proposals for personal bankruptcies were filed in 2012 alone. We can assume that already during the course of 2013, the number of personal bankruptcies in the Czech economy will reach a level of fifty thousand cases and will rise dynamically.

We would like to continue these considerations in a construction of our model.

Table 6

Model of the Relationship of Credit, Deposits, Unemployment Rate and Savings in 1993-2011 (in logarithms)

\begin{tabular}{|l|c|c|c|c|}
\hline \multicolumn{5}{|c|}{ Dependent variable LCREDITS } \\
\hline Variable & Coefficient & Std. Error & t-Statistic & Prob. \\
\hline LCREDITS(-1) & 0.930394 & 0.034929 & 26.63641 & 0.0000 \\
\hline LDEPOSITS & 0.179788 & 0.064277 & 2.797078 & 0.0174 \\
\hline LUNEMPRATE & -0.365738 & 0.118401 & -3.088967 & 0.0103 \\
\hline LUNEMPRATE(-1) & 0.309897 & 0.090998 & 3.405544 & 0.0059 \\
\hline LSAVINGS(-1) & -0.569942 & 0.183168 & -3.111581 & 0.0099 \\
\hline $\mathbf{R}^{2}=\mathbf{0 . 9 9 6 5 3 3}$ & & \multicolumn{3}{|c|}{ Prob. $=0.2872$} \\
\hline Breusch-Godfr. Ser. Corr. LM test $=\mathbf{1 . 4 3 7 5}$ & & Prob. $=0.9833$ \\
\hline Heteroskedasticity Test $=\mathbf{0 . 0 0 0 5}$ & & \\
\hline Jarque-Bera Test $=\mathbf{0 . 5 5 2 7}$ &
\end{tabular}

Source: author's calculation

The ADL model (Table 6) capturing the dependency of credits to other indicators can be written in the form

$$
\begin{aligned}
& \log \left(\text { CREDITS }_{t}\right)=0.930394 \log \left(\text { CREDITS }_{t-1}\right)-0.365738 \log \left(\text { UNEMPRATE }_{t}\right)+ \\
& \quad+0.309897 \log \left(\text { UNEMPRATE }_{t-1}\right)+0.179788 \log \left(\text { DEPOSITS }_{t}\right)- \\
& \quad-0.569942 \log \left(\text { SAVINGS }_{t-1}\right)+a_{t} .
\end{aligned}
$$

In order to identify short-term and long-term relationships, we transcribe the equation into the form of an EC model 


$$
\begin{gathered}
\Delta\left(\log \left(\text { CREDITS }_{t}\right)\right)=-0.365738 \Delta\left(\log \left(\text { UNEMPRATE }_{t}\right)\right)+ \\
+0.179788 \Delta\left(\log \left(\text { DEPOSITS }_{t}\right)\right)-0.06961\left[\log \left(\text { CREDITS }_{t-1}\right)\right)- \\
-0.80224 \log \left(\text { UNEMPRATE }_{t-1}\right)+ \\
\left.+2.582938 \log \left(\text { DEPOSITS }_{t-1}\right)-8.18812 \log \left(\text { SAVINGS }_{t-1}\right)\right]+a_{t} .
\end{gathered}
$$

From the perspective of short-term relationships, credits in time $t$ depend very heavily on the volume of credits in time $t-1$, on the unemployment rate in time $t$ and $t-1$, on the deposits in time $t$ and $t-1$ and on the savings in time $t-1$ (all tests are conducted on a $5 \%$ significance level). By means of the parameter $\gamma=0.06961$, we receive the information about the speed with which the system reacts to the deviations from the equilibrium. The long-term relationship is expressed by the term EC, which is given by the equation

$$
\begin{gathered}
\log \left(\text { CREDITS }_{t}\right)=0.8022 \log \left(\text { UNEMPRATE }_{t}\right)-2.58294 \log \left(\text { DEPOSITS }_{t}\right)+ \\
+8.1881 \log \left(\text { SAVINGS }_{t}\right) .
\end{gathered}
$$

It is clear that credits directly depend proportionally to the unemployment rate and the savings rate and indirectly proportionally to deposits.

The diagnostic check of the model in Table 6 indicates that the non-systematic part of the model has the properties of the white noise process (Breusch, Godfrey, 1986; Jarque, Bera, 1980; Darnell, 1994; Arlt, Radkovský, 2000). We will interpret these relationships later.

\section{Basic Conclusions}

The submitted data and facts imply one fundamental conclusion: the standard of living of Czech families was substantially subsidised by two types of debt in the past years.

First, it was subsidised by sovereign debt, expressed as state budget deficit. We have only used 75 percent of this debt to formulate our conclusions, stating that a part of the debt did not inevitably have to be transferred to family incomes and could have been used for imports of goods and services for the public sector instead.

Second, it was subsidised by direct family debt, obtained from banks and other financial institutions.

All in all, we have found out that these transfers of debt ranged between 5.3 percent and 14.8 percent of available household income. The average share of debt in the available income of Czech families amounted to 9.44 percent in the ten years covered by our study.

With some overstatement, we can claim that the living standard of Czech households has exceeded the standard that would have been possible given the true condition of the Czech economy, work productivity and effective use of resources by about ten percent in the long run. 
This bold conclusion could certainly be relativized by referring to the comparatively significant volume of financial savings of households that had been attained already during the communist era, when the assortment generated by the socialist economic system did not enable families to turn their available resources into consumption. The level of savings was high even during the first transformation period at the beginning of the 1990s of last century and was in fact relatively high also during the observed years. Against this, however, we can advance several other arguments which support the assertions above. Let us at least choose the fact that, until the end of 2011, no truly significant reform of the pension system had been undertaken in the Czech Republic, which markedly relativizes any financial savings in the long-term horizon. Moreover, from this it follows that families were not forced to carry their part of the expenses for realising such reforms; these will without doubt be enormous expenses and we can (of course, only lineally) confidently compare them even to the entire volume of household financial savings in their state at the end of 2011. The fact that these expenses have not been forced until now in no way reduces the elementary fact that they will be forced sooner or later. Let us note only very briefly, then, that one of the reasons why a long-term reform of the pension system will be an absolute necessity is given by demographic developments in the country and the reality of very low natality. Purely economically, we could then consider whether lowering family reproduction costs (i.e. lowering costs for the next generation), which occurred in the 1990s of last century and in the entirety of our century until now, will be implemented into significantly higher pension reform costs. We also freely calculate into the expenses of the "pension reform" the fact that low future pay-outs from the pension system will be reflected in the need to draw much further from the financial reserves of those families that will, in terms of time, be affected by the emerged discrepancy.

Furthermore, we have some conclusions derived from the mathematical analytical models that must be interpreted. First of all, we can observe a sharp and documented growth of the proportion between the funds loaned to families and the families' financial savings. This growth has gained enormous speed in recent years, and it is difficult to avoid the feeling that for some groups of the population, it must have a fatal impact on the stability of their family budgets.

Of course, all the figures used have been strongly generalised and therefore do not allow for the families' analysis based on social, regional or other criteria. However, it is obvious that many families, especially from the lowest income groups (the first quintile), are very unlikely to have any savings whatsoever and that, on the contrary, their budget is encumbered by substantial debt, at least compared to their regular income. Moreover, many families belonging to high-income groups are very likely to have assumed so many liabilities (especially mortgage-related liabilities) that they have lost their ability to repay primarily as real wages have dropped due to the economic crisis. Both of these conclusions are confirmed by the data on the development of family defaults in the Czech Republic and, above all, the data on the number of property seizures and various types of auctions. 
Therefore, it will be necessary and very useful to analyse data not generally but with emphasis on distribution among the individual income groups - either by quintiles or deciles - in future research.

Similarly, it will be appropriate to utilise in forthcoming investigations the approaches and methods outlined here for work with more detailed, structured data - especially where savings and, on the contrary, liabilities of families are concerned. It will therefore be appropriate to work also with such concepts as net financial family reserves (but for the purposes of this investigation it will be necessary to define this term precisely in its relationship to the general wealth of families as to a category which Eurostat uses in its investigations). In the area of household debt, it will be fitting to distinguish more precisely between short and long-term debt. This ratio does not play an important role in the investigations presented here as it is practically not significant whether the debt was utilised for increasing immediate consumption or for ensuring long-term consumption (such as housing); if we wanted to undertake a deeper analysis of the problem, however, and draw some more comprehensive conclusions therefrom, it would be necessary to take this aspect into consideration.

It would also be interesting to work with a more careful distinction between households (whereas in the interests of improved readability of the text we use the term families, which appears as a synonym for households). The possibility of examining households in their income structure or from the perspective of numbers of family members would be unusually thought provoking, but the necessary data for this are presently unavailable.

In forthcoming investigations, it might also prove beneficial to work not only with government (state) budget deficits as the primary source of government (state) debt, but also with the deficit of the entire public sector, including deficits of municipalities and regions, possibly also with the deficit in the economic management of certain government (state) institutions, which is not transferred directly into the results of government (state) budgets, but is covered by different means for which the government (state) only takes over a guarantee. From the methodological perspective it would be more precise, even though we would in fact not arrive at any fundamentally different results. From the perspective of public debt as a whole, government (state) debt is absolutely crucial, which even leads to imprecise confusion of these terms.

\section{Additional Conclusions and Criticism}

The interpretation of the conclusions ensuing from Table 4 must be thoroughly clear. In the entire time series from the beginning of the reforms until the end of 2010, each growth in household deposits goes hand in hand with growth in credit obtained - although the margin by which credits prevail over deposits is relatively small, it is nevertheless of paramount importance in the long run.

Credit prevailing over deposits is a characteristic sign for the Czech Republic despite the demonstrable pressure of the unemployment rate over household credit, as indicated 
by the results summarised in Table 4 . We can see the result of this pressure primarily in the years 2009 and 2010 in Figure 2, when we observe the deceleration of further rate of growth in the proportion between deposits and credit provided to households.

Linking this data and these results to the theory that the growth in the standard of living enjoyed by Czech households was to a substantial degree (we mentioned ten percent) fed by debt in roughly the last ten years, the results of the mathematical analyses summarised in Table 6 create a logical unit with this theory.

The interpretation of the results summarised in Table 6 , then, is highly problematic. Here, besides the relationship of deposits and credits and unemployment, the savings rate approaches as a parameter which in itself carries purification from inflationary influences (inflation is contained in all departure-point data from which this information arises) and thereby relativizes the volume indicators in their proportion to the unemployment rate. But if we wanted to draw some basic conclusions from the ascertained dependencies, we would primarily arrive at the conclusion that the direct extent to which the common proportion indicators (the unemployment rate and the savings rate) affect the volume indicator of savings suggests that it will be very difficult, in an environment of prevailing high unemployment, to balance any imbalances in these financial models. The conclusions that stem from Table 4 are thereby still raised to a higher power.

This conclusion could be applied to a number of other countries, especially those that witnessed a dramatic increase in sovereign or household debt. We must not forget that if we disregarded the crisis years of 2008 through 2010, the sovereign debt of most developed countries would stagnate or drop, i.e. budgets would in principle be balanced or the deficits lower than debt service. However, the debt of families rose and eventually exceeded the GDP and reached double the annual available income of families in many countries in the same period of time. A thorough analysis would be required for more accurate conclusions.

What further conclusions can be drawn from the statement that about ten percent of the standard of living of Czech families has been made possible by increasing (sovereign or family) debt in the past decade? If we could say that household income will witness a dynamic rise and that the states' gross domestic product will grow in general to the degree that these states will not be forced to reduce the households' available income through taxes, this finding would not be very important. However, from today's perspective (in January 2013), we must foresee a different scenario: continued stagnation and the governments requiring its citizens to pay higher taxes to settle their liabilities.

This means that neither sovereign nor household debt can be settled in the upcoming years otherwise than through a reversal of the trend witnessed in the past decade, i.e. by debt repayment at the expense of the citizens' true standard of living.

Of course, this leads to many questions that move from the domain of economics to the domain of politics and partly political science. The most important of these questions is the relatively simple question of whether political representations of developed 
countries will be able to defend the need to reduce the standard of living before the citizens and, therefore, whether they can obtain sufficient electoral support for this need of their national economies - as we have already seen, the process of reducing public and family debt will entail, on the one side, a change in the standard of living, primarily for a significant portion of the population of the countries that have taken on major government and family debts. In addition, there could be strong pressure for compensation of the dropping standard of living suffered by the relatively poorer groups by a redistribution of wealth through budgets, which, however, must inevitably negate any efforts to reduce government debts.

\section{References}

Arlt, J. (1997), "Regresní analýza nestacionárních ekonomických časových řad." Politická ekonomie, Vol. 45, No. 2, pp. 281-289.

Arlt, J., Arltová, M. (2009), "Ekonomické časové řady." Prague: Professional Publishing.

Arlt, J., Radkovský, Š. (2000), "Význam modelování a předpovídání volatility časových řad pro řizení ekonomických procesư". Politická ekonomie, Vol. 48, No. 1, pp. 38-61.

Breusch, T., Godfrey, L. G. (1986), "Data Transformation Tests”. Economic Journal, 96 (Souplement), pp. 47-58.

Czech Statistical Office (2009), "Vývoj cen, příjmů a spotřebních vydání domácností v letech 2000 až 2008." [Online]. Available at http://www.czso.cz/csu/2009edicniplan.nsf/p/1155-09.

Czech Statistical Office (2012). "Stav vkladů a půjček domácností celkem.” [Online]. 2012. Available at http://www2.czso.cz/csu/2012edicniplan.nsf/t/E50025C7D0/\$File/140312q307.xls.

Darnell, A. C. (1994), A Dictionary of Econometrics. Aldershot: Edward Elgar.

Dickey, D. A., Fuller, W. A. (1979), "Distribution of the Estimators for Autoregressive Time Series with a Unit Root". Journal of the American Statistical Association, Vol. 74, No. 366, pp. 427-431.

Dubská, D. (2010), “České domácnosti dluží bilion.” Čsú, [Online]. Available at http://www.czso.cz/ csu/csu.nsf/informace/ckta120310.doc.

Engle, R. F., Granger, C. W. J. (1987), "Cointegration and Error Correction Representation: Estimation and Testing." Econometrica, Vol. 55, pp. 251-276.

Granger, C. W. J., Newbold, P. (1974), "Spurious Regression in Econometrics." Journal of Econometrics, Vol. 2, No. 2, pp. 111-120.

Hendry, D., Pagan, A., Sargan, J. (1984), "Dynamic Specifications.” in Griliches, Z., Intriligator, M. (eds.,) Handbook of Econometrics, Vol. II, Chapter 18. Amsterdam: North Holland.

Holman, R. (2005), Dějiny ekonomického myšlení. $3^{\text {rd }}$ Edition. Praha: C. H. Beck.

Jarque, C., Bera, A. (1980), "Efficient Tests for Normality, Heteroscedasticity, and Serial Independence of Regression Residuals". Economics Letters, Vol. 6, pp. 255-259.

OECD iLibrary (2011), "Government at a Glance". [Online]. Available at http://www.oecd-ilibrary.org.

Smrčka, L. (2009), "State Intervention as the Trigger and Accelerator of the Global Crisis which Started in 2007". In ICABR 2009 [CD-ROM], Brno, pp. 1308-1320.

Tučková, Z, Strouhal, J. (2010), "Knowledge-Intensive Services: New Leader of Production Stages?" WSEAS Transactions on Systems, Vol. 9, No. 1, pp. 432-441.

The Market Oracle (2012), "Say Goodbye to Your Standard of Living, Inflating Away America's Future." [Online]. Available at http://www.marketoracle.co.uk/Article28876.html. 